\title{
Measuring the Role of Trust in M-Commerce Acceptance: An Empirical Analysis in Context of Pakistan
}

\author{
MUHAMMAD MALOOK RIND*, IMRAN ALI QURESHI **, AND ABDUL QADIR ANSARI*** \\ RECEIVED ON 15.03.2016 ACCEPTED ON 11.05.2016 \\ ABSTRACT
}

\begin{abstract}
With the emergence of internet and WWW (World Wide Web), traditional businesses got a new opportunity to compete globally. A new term of M-Commerce (Mobile Commerce) emerged and set a new trend in commerce and business. Traditional bricks-and-mortar businesses became e-business (electronic business) with the help of ICT (Information \& Communication Technology) tools. Evidences from literature review suggest that there has been little growth in the acceptance of M-commerce in developing economies such as Pakistan as compared to developed economies. There are doubts that users of M-commerce demonstrate a lack of enthusiasm, which may be because of the lack of trustworthiness. Based on the well-known and widely used TAM (Technology Acceptance Model), this study provides the theoretical underpinning and empirical evidence between the relationships of trust construct with the adoption of $\mathrm{M}$ commerce in Pakistan. A cross sectional questionnaire survey was conducted to collect data from Mcommerce users in Pakistan to check the influence of trust. After the analysis of 390 valid responses obtained results indicate that trust and other constructs of TAM are related and there is positive and significant role of trust in the acceptance of M-commerce in Pakistan. Results also prove the hypothesized relationship among all constructs of proposed Model.
\end{abstract}

Key Words: Mobile Commerce, Pakistan, Technology Acceptance Model, Perceived Usefulness, Perceived Ease of Use, Trust.

\section{INTRODUCTION}

$\mathrm{R}$ apid developments in the field of Information and M-commerce technologies has provided go beyond physical boundaries and step ahead towards the fast take-off in electronic (E-commerce) and $\mathrm{M}$ commerce. According to [1] the future of business transactions are now in M-commerce activities. In recent past M-commerce has emerged to be new horizons of opportunities for doing business and commerce activities with the help of mobile handheld devices [2]. M-commerce can be defined as the exchanging of services and goods or selling and buying of services and goods by using wireless handheld devices including smart phones, cellular phones, tablet computing devices, personal data assistants, and laptop computers [3]. Although unique features of M-commerce provide abundant flexibility to

\footnotetext{
* Kulliyyah of Information \& Communication Technology, International Islamic University, Malaysia.

** Department of Telecommunication Engineering, Mehran University of Engineering \& Technology, Jamshoro.

** Department of Biomedical Engineering, Mehran University of Engineering \& Technology, Jamshoro.
} 
its users regarding time and place, but it is found that still customers have been reluctant to adopt it [4]. Since, in $\mathrm{M}$-commerce the medium of transactions is actually a virtual environment, users usually feel uncomfortable to provide their personal and financial details, due to lack of trust, uncertainty and potential risk associated with virtual online environments [5]. Large scale adoption of commercial activities on the web is perceived to be limited because of mistrust between the buyers and sellers [5]. The role of trust is important in M-commerce since most of the time users are unaware of the vendor's credibility of the service delivery.

Mobile phone usage in Pakistan is increasing very rapidly due to cheaper rates of telecom services and increasing competition among mobile service operators. As per Pakistan telecommunication authority [6] total cellular teledensity has reached to $70.4 \%$, which predicts huge opportunity for M-commerce market in Pakistan. Although, telecommunication infrastructures and mobile services in Pakistan has seen high penetration since telecom deregulation policy introduced by Ministry of IT and Telecommunication since 2000, however, so for, adoption of services like M-commerce has been lethargic [7]. Understanding the importance of trust factor in the adoption of technologies like M-Commerce is of significant concern for the organization offering online services in developing economies same as Pakistan before making huge investment in the sector. Therefore, the purpose of this study is to fill the gap in literature and thereby make a significant contribution by examining and identifying the degree to which trust influences the acceptance M-Commerce in Pakistan. As, M-commerce market in Pakistan is in early phases the results of this research can help M-commerce operators in understanding user's intention related to trust in the adoption of M-commerce in a more sophisticated way.

\section{RESEARCH BACKGROUND}

\subsection{Trust in M-Commerce Perspective}

Being an important element in commerce or business deals, trust has sought universal interest both in research and practice. The role of trust becomes more important if business or commerce deals are done with information technology enabled systems like E-commerce and Mcommerce, where customers have concerns about their privacy and security [8-10]. Trust is a complex, contextdependent, multi-dimensional construct. Thus the meaning of trust has a different understanding in different contextual settings $[5,11]$ suggest that "trust imitate a willingness to be in susceptibility based on the positive expectation toward another party's future behavior". Trust is therefore an important consideration while performing transactions through internet, as the customers need to have enough trust on other party while putting themselves in a vulnerable situation. Trust depends on three beliefs: integrity, ability, and benevolence [12]. Integrity relates to service providers promises that, never to deceive customers. Ability relates to service provider's ability and knowledge which is necessarily required to fulfill their tasks. In online commerce context initial trust has received considerable attention due to its significant role. Reputation, information quality, company size, willingness to customize and website qualities are identified as significant factors to affect the initial trust built up in online environment [13-15]. Regarding online business environment [16] also identified trust as a crucial element of online business activities since there is an uncertain and open nature of web-based systems and internet which are the only medium for financial transaction in the global environment.

\subsection{Research Context: Pakistan}

Having GDP of 246.9 billion dollars (as of year 2015 statistics) with the growth rate of $3.7 \%$ per annum, 
Pakistan is the sixth most populous country in the world with total population of 185.1 million [17]. As per Pakistan Telecommunication Authority [6] statistics, the number of cellular mobile phone users in Pakistan reached 139.20 million at the end of May 2014. Thus, Pakistan is the fifth largest mobile phone base in Asia [17]. Pakistani users have not paid much attention towards the usage of Mcommerce as compared to western world [18]. In Pakistan, the highest proportions of M-commerce users are the youth individual. This gives a rising exposure to the retailers to increase their investment in this sector [19]. Compared to other countries, online shopping is not in competitive condition in Pakistan [18]. After huge investment in IT \& telecom sector and announcement of new IT policies in 2000 , there has been a gradual proliferation in mobile phone and internet users. There are nearly 7 billion mobile subscriptions worldwide, which is equivalent to $95.5 \%$ of the world population [20]. Among top 14 mobile markets by number of subscriptions worldwide, Pakistan is ranked on 8th.

\section{RESEARCH MODELAND HYPOTHESIS}

\subsection{Proposed Research Model}

Various methods have been adopted to analyze the important factors which predict the user's intention behavior in particular contextual settings. On the basis of reviewed literature, TAM is the most suitable and widely used theory in IS and IT field to measure individual's acceptance and use behavior. TAM provides good understanding of most influential factors in acceptance, adoption, usage or rejection of IT and IS [21]. Due to large scale acceptance, robustness and clear focus on IT/IS usage [22], TAM is taken as a baseline model in this research. Along with core constructs of TAM, namely, PEOU (Perceived Ease of Use) and PU (Perceived Usefulness), trust is integrated as an additional variable. Previous research provide good evidence of the impact of trust on the behavior intention and PU [22-25].

In summary, the proposed research model (Fig. 1) intends to find individual's intention towards the usage of Mcommerce having combined effect of perceived usefulness, perceived ease of use and trust. The emphasis of proposed model is on explaining the impact trust on behavioral intention to use M-commerce in Pakistan's context.

\subsection{Behavioral Intention}

Most of the IS and IT system usage theories and literature define "Actual usage" as a key construct in their framework. However, new research focused on TAM,

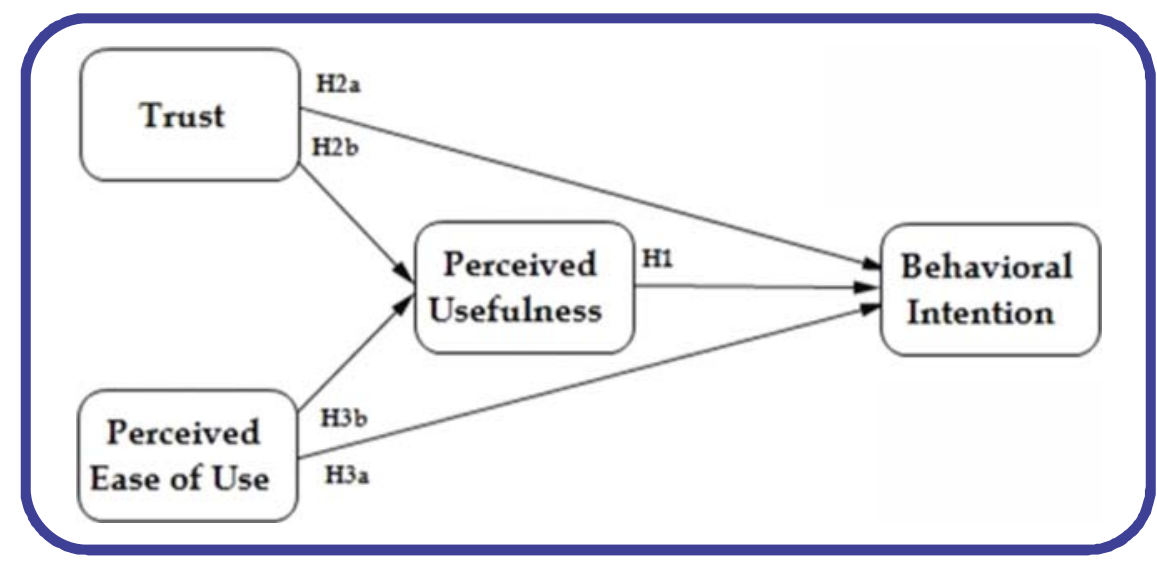

FIG. 1. RESEARCH MODEL 
often use BI (Behavior Intention) to measure the individual's acceptance and adoption of IT and IS [22]. According to Davis [26] BI is an extent to which an individual intends to perform a specific behavior. Thus, as per TAM the impact of usefulness and ease of use is fully mediated towards the behavioral intention. In MCommerce context it is the user's likelihood to engage in online transaction using their handheld mobile devices.

\subsection{Perceived Usefulness}

PU is an individual's belief that using a particular technology or systems can enhance his or her performance [26]. Furthermore it is a degree to which individual believe that the use of M-Commerce can improve his daily activities [3]. PU is found to have an positive effect on the adoption of mobile data services [27,28]. Many researchers identified that $\mathrm{PU}$ is a major factor that influences the adoption of ICT oriented services $[8,26,29$ 32]. PU plays a pivotal role in usage of web portals and acceptance of mobile commerce services [33]. Consistent with the prior studies, it is hypothesized that:

H1: PU will have a positive significant effect on behavioral intention to accept M-Commerce.

\section{$3.4 \quad$ Trust}

While conducting online purchase or transaction activity customers feel anxious about sharing their personal information to third party which in this case is virtual [31]. There are both empirical and theoretical evidences regarding a considerable relationship between trust and BI. [34], in their research study, found evidences that behavioral intention is influenced by trust [23], empirically proved significant effect of trust on purchase intention and that, trust increases the individual's intention to use the M-commerce. Some other researchers also found significant relationship between trust and PU [5]. Similarly, [31] provided evidence that trust has positive impact on
PU and allows customers to become more vulnerable to the expectation that they would receive the predictable services or goods from the trusty vendors. Thus, on the basis of prior research, it is hypothesized as follows:

H2(a): Trust will have a positive significant effect on behavioral intention to accept M-Commerce.

H2(b): Trust will have a positive significant effect on perceived usefulness to accept M-Commerce.

\subsection{Perceived Ease of Use}

PEOU can be defined as an extent and individual's selfconfidence which he or she claims is free of effort [26]. PEOU reflects the extent of perceived efforts in using MCommerce [35]. Research studies related to TAM suggest that PEOU has direct or indirect effect on behavioral intention[36]. Literature review shows that PEOU is an important determinant for the acceptance and adoption of IT Systems, like 3G [37], online banking [22,38] Mobile services [39], M-Payments [28] and M-Commerce [40,41]. Thus, we hypothesize that:

H3a PEOU will have a positive significant effect on behavioral intention to accept M-Commerce.

H3b PEOU will have a positive significant effect on Perceived usefulness to accept M- Commerce.

\section{METHODOLOGY}

\subsection{Questionnaire Development}

In order to assess the impact of trust of Pakistani customers in using M-commerce a structured survey instrument was developed for data collection. Good questionnaire design principles were employed in questionnaire development process, such as avoidance of leading questions and use of positive questions as recommended by [22]. Although, items for each construct were adopted from previous research studies done in

Mehran University Research Journal of Engineering \& Technology, Volume 36, No. 2, April, 2017 [p-ISSN: 0254-7821, e-ISSN: 2413-7219] 
context of IS/IT; experts/practitioners were involved to improve the wording and technical expressions to make questionnaires easily understandable to common Mcommerce users. For all four constructs used in proposed framework a total of 24 items were finalized (see Appendix A). For BI all five items were adapted from [26], seven items for PU were adapted from [26,42], seven items for PEOU were also adapted from $[26,42]$. However six items related to trust were adapted from $[5,43]$. SevenpointLikert scale from (1) strongly disagree to (7) strongly agree was used to measure all items related to all four constructs of proposed model. While demographic related information was measured on a nominal scale. As per recommendation of various IS/IT related researcher $[22,26,42,44]$ seven-point rating scale helps to better understand individual's agreement level for a given statement.

\subsection{Sampling and Data Collection}

A cross sectional quantitative survey questionnaire was used to collect data from M-commerce users located in five major cities of Pakistan including Lahore, Karachi, Quetta, Peshawar and Islamabad. In order to have sample representation of the whole population it is supposed that major population for our survey belongs to these five cities which can be identified as clusters. These clusters which occurred naturally in the population helped us save money and time. Furthermore participants in these five clusters were selected randomly in educational institutes, banks, organizational headquarters, shopping malls, town centers, and train stations. Participants which had experience in online shopping in particular Mcommerce were requested for voluntary participation in the survey. Regarding sample size, [45] gave rating to different sample sizes and believed that a sample size of 50 is very90poor, 100 is poor, 200 is fair, 300 is good, 500 is very good, and 1,000 is an excellent. Moreover, [46] also claimed that to achieve optimal results a sample size of at least 200 and not exceeding 400 would be a better approach.

\section{EMPIRICAL STUDY}

\subsection{Descriptive Statistics}

In field survey, approximately 600 questionnaires were distributed and after continuous follow-up activities 435 responses received. Out of which, 20 respondents provided incomplete response, 20 indicated they have never used internet and 5 provided completely blank copies of questionnaires. Thus, 390 valid responses were used for data analysis.

Table 1 portrays the descriptive statistical results based on the demographic data received from the respondents. Since internet and online shopping trend is new, results indicate that youngsters within the age bracket of 21-30 years and less are more interested and have highest proportion of approximately $60 \%$ of respondents. Results also indicate that, although online shopping activities are performed by approximately all age brackets of respondents but only 55\% users have been using MCommerce, while $45 \%$ of respondents have never used or reluctant towards M-commerce.

\subsection{Measurement Model}

SEM (Structural Equation Modeling) is one of the well accepted statistical data analysis technique most, commonly used for estimating, representing, and testing the relationships between variables (measured and latent constructs) [47]. We used IBM AMOS 21 for SEM to analyze the role and measure the hypothesized relationships among variables of proposed framework. According to the recommendation of [48], SEM should be done in two steps, first the assessment of convergent and discriminant validity of construct should be performed using MM (Measurement Model) approach, while in second step proposed hypotheses testing should be done using SM (Structural Model) approach.

Mehran University Research Journal of Engineering \& Technology, Volume 36, No. 2, April, 2017 [p-ISSN: 0254-7821, e-ISSN: 2413-7219] 
TABLE 1. DEMOGRAPHIC STATISTICS

\begin{tabular}{|c|c|c|c|c|}
\hline Variable & Category & Frequency & Percent $(\%)$ & Cumulative \\
\hline \multirow{2}{*}{ Gender } & Male & 263 & 67.4 & 67.4 \\
\hline & Female & 127 & 32.6 & 100.0 \\
\hline \multirow{6}{*}{ Age } & $<20$ & 4 & 1.0 & 1.0 \\
\hline & $21-30$ & 231 & 59.2 & 60.3 \\
\hline & $31-40$ & 124 & 31.8 & 92.1 \\
\hline & $41-50$ & 24 & 6.2 & 98.2 \\
\hline & $51-60$ & 5 & 1.3 & 99.5 \\
\hline & $>60$ & 2 & 0.5 & 100.0 \\
\hline \multirow{5}{*}{ Education } & High school & 2 & 0.5 & 0.5 \\
\hline & Intermediate & 3 & 0.8 & 1.3 \\
\hline & Diploma & 6 & 1.5 & 2.8 \\
\hline & Bachelor & 250 & 64.1 & 66.9 \\
\hline & Postgraduate & 129 & 33.0 & 100.0 \\
\hline \multirow{5}{*}{ Occupation } & Student & 116 & 29.7 & 29.7 \\
\hline & Government employee & 118 & 30.3 & 60 \\
\hline & Private sector & 131 & 33.6 & 93.6 \\
\hline & Businessperson & 8 & 2.1 & 95.6 \\
\hline & Other & 17 & 4.4 & 100.0 \\
\hline \multirow{6}{*}{ Income (rupees) } & $<20,000 \mathrm{Rs}$ & 126 & 32.3 & 32.3 \\
\hline & $21,000-40,000 \mathrm{Rs}$ & 98 & 25.1 & 57.4 \\
\hline & $41,000-60,000 \mathrm{Rs}$ & 64 & 16.4 & 73.8 \\
\hline & $61,000-80,000 \mathrm{Rs}$ & 56 & 14.4 & 88.2 \\
\hline & $81,000-100,000 \mathrm{Rs}$ & 24 & 6.2 & 94.4 \\
\hline & $>100,000 \mathrm{Rs}$ & 22 & 5.6 & 100.0 \\
\hline \multirow{5}{*}{$\begin{array}{l}\text { Online shopping } \\
\text { experience }\end{array}$} & $<1$ Year & 54 & 13.8 & 13.8 \\
\hline & 2-3 Years & 85 & 21.8 & 35.6 \\
\hline & 3-4 Years & 104 & 26.7 & 62.3 \\
\hline & 4-5 Years & 42 & 10.8 & 73.1 \\
\hline & $>5$ Years & 105 & 26.9 & 100.0 \\
\hline \multirow{5}{*}{$\begin{array}{l}\text { M-Commerce usage } \\
\text { frequency }\end{array}$} & Weekly & 56 & 14.4 & 14.4 \\
\hline & Monthly & 67 & 17.2 & 31.5 \\
\hline & Quarterly & 51 & 13.1 & 44.6 \\
\hline & yearly & 40 & 10.3 & 54.9 \\
\hline & Never & 176 & 45.1 & 100 \\
\hline \multirow{5}{*}{ Name of City } & Karachi & 91 & 23.3 & 23.3 \\
\hline & Islamabad & 83 & 21.2 & 44.5 \\
\hline & Lahore & 81 & 20.7 & 65.2 \\
\hline & Peshawar & 72 & 18.4 & 83.6 \\
\hline & Quetta & 63 & 16.1 & 100 \\
\hline
\end{tabular}

Mehran University Research Journal of Engineering \& Technology, Volume 36, No. 2, April, 2017 [p-ISSN: 0254-7821, e-ISSN: 2413-7219] 
CFA (Confirmatory Factor Analysis) technique is helpful in establishing the construct validity of proposed MM $[46,48]$. CFA was run on the MM for the empirical assessment of convergent validity of measurement model. All 24 items related to four constructs (Appendix-A) namely; BI, PU, PEOU, and TR were measured in CFA. Standardized residual results indicated that the values of PU7 (related to PU construct), PEOU4 and PEOU7 (related to PEOU construct) found out of the acceptable limits (above 2.58 or below -2.58). These items were dropped due to high degree of residual variance. As per recommendation of $[46,49]$, after dropping the problematic items MM needs to be re-run again. Table 2 illustrates the factor loadings of proposed model, results show that values of all items related to four constructs exceed the threshold limit of 0.5 and all found significant. Internal consistency of each measure was identified by Cronbach's alpha. All the scale-wide reliability coefficients values found between 0.752-0.930 (Table 2) which are exceeding the recommended values of 0.70 [46], and suggest adequate scale reliability. As per requirement and recommendation, CR (Composite Reliability) values should exceed AVE (Average Variance Extracted), results indicate the all $\mathrm{CR}$ values exceed the threshold limit of 0.6 , thus the valid results of convergent validity requirements are achieved.

TABLE 2. VARIABLES, FACTOR LOADING, RELIABILITY AND VALIDITY VALUES

\begin{tabular}{|c|c|c|c|c|c|}
\hline Construct & Item Code & Factor Loading & Cronbach's (?) & Composite Reliability & $\begin{array}{c}\text { Average Variance } \\
\text { Extracted }\end{array}$ \\
\hline \multirow{5}{*}{ Behavioral Intention } & BI1 & 0.826 & \multirow{5}{*}{0.930} & \multirow{5}{*}{0.931} & \multirow{5}{*}{0.728} \\
\hline & BI2 & 0.856 & & & \\
\hline & $\mathrm{BI} 3$ & 0.876 & & & \\
\hline & BI4 & 0.859 & & & \\
\hline & BI5 & 0.849 & & & \\
\hline \multirow{6}{*}{ Perceived Usefulness } & PU1 & 0.804 & \multirow{6}{*}{0.895} & \multirow{6}{*}{0.908} & \multirow{6}{*}{0.612} \\
\hline & PU2 & 0.824 & & & \\
\hline & PU3 & 0.862 & & & \\
\hline & PU4 & 0.859 & & & \\
\hline & PU5 & 0.862 & & & \\
\hline & PU6 & 0.853 & & & \\
\hline \multirow{5}{*}{ Perceived Usefulness } & PEOU1 & 0.870 & \multirow{5}{*}{0.752} & \multirow{5}{*}{0.927} & \multirow{5}{*}{0.718} \\
\hline & PEOU2 & 0.873 & & & \\
\hline & PEOU3 & 0.788 & & & \\
\hline & PEOU5 & 0.847 & & & \\
\hline & PEOU6 & 0.856 & & & \\
\hline \multirow{6}{*}{ Trust } & TR1 & 0.816 & \multirow{6}{*}{0.917} & \multirow{6}{*}{0.918} & \multirow{6}{*}{0.650} \\
\hline & TR2 & 0.807 & & & \\
\hline & TR3 & 0.803 & & & \\
\hline & TR4 & 0.785 & & & \\
\hline & TR5 & 0.858 & & & \\
\hline & TR6 & 0.765 & & & \\
\hline
\end{tabular}

Mehran University Research Journal of Engineering \& Technology, Volume 36, No. 2, April, 2017 [p-ISSN: 0254-7821, e-ISSN: 2413-7219] 
The MM indicates fairly reasonable results (Table 3 for model fit indices), i.e. absolute fit measures such as $\mathrm{x}^{2} / \mathrm{df}$ found 1.693, GFI (Goodness-of-Fit Index) found 0.920 and RMSEA (Root Mean Square of Approximation) found 0.042 . Similarly incremental fit measures such as CFI (Comparative Fit Index) and NFI (Normated Fit Index) found 0.978 and 0.948, respectively. However, the parsimony fit measures like AGFI (Adjusted Goodness of Fit Index) found 0.90. Thus all these statistics results indicate that the model fits the data adequately.

By making the comparison of the AVE estimates for the corresponding constructs with the squared interconstruct correlations, results indicate that the AVE of each construct are greater than the corresponding squared inter construct correlation. Thus the results shown in Table 4 provide additional support of discriminant validity $[46,50]$.

\subsection{Structural Model}

SM with AMOS helps to confirm the hypothesized relationships among the constructs. According to [49] SM helps to evaluate that which constructs directly or indirectly affects the values of other constructs in the proposed model. Table 5 shows hypothetical relationships, standardized regression coefficients, and t-values. Results show that all five hypothesis (H1, $\mathrm{H} 2 \mathrm{a}, \mathrm{H} 2 \mathrm{~b}, \mathrm{H} 3 \mathrm{a}, \mathrm{H} 3 \mathrm{~b}$ ) are highly significant (i.e. p-values is $<0.001$ ) and highly positive significant coefficients path is between PEOU and PU ( $\beta$-value 0.428, t-value 9.180). However, there is least positive significant coefficient path between BI and PEOU (â-value 0.161, t-value 3.595). Fig. 2 shows the model supported by the empirical data.

\section{DISCUSSION}

Motivated by the need to identify the factors influencing customer acceptance of M-commerce and the impact of trust, we conducted a cross-sectional self administrated quantitative survey and analyzed the results with

TABLE 4. DISCRIMINANT VALIDITY

\begin{tabular}{|c|c|c|c|c|}
\hline Hypothesis & Relationship & $\begin{array}{c}\text { Structural } \\
\text { Coefficients }\end{array}$ & CR (t-Value) & Remarks \\
\hline H1 & PU'BI & $0.359 * * *$ & 7.937 & \multirow{5}{*}{ Supported } \\
\hline $\mathrm{H} 2 \mathrm{a}$ & TR'BI & $0.412 * * *$ & 9.324 & \\
\hline $\mathrm{H} 2 \mathrm{~b}$ & TR'PU & $0.263 * * *$ & 6.029 & \\
\hline $\mathrm{H} 3 \mathrm{a}$ & PEOU'BI & $0.161 * * *$ & 3.595 & \\
\hline $\mathrm{H} 3 \mathrm{~b}$ & PEOU'PU & $0.428 * * *$ & 9.180 & \\
\hline
\end{tabular}

TABLE 5. REPORT OF HYPOTHESES TESTING

\begin{tabular}{|c|c|c|c|c|}
\hline & PU & TR & BI & PEOU \\
\hline PU & 0.783 & & & \\
\hline TR & 0.601 & 0.806 & & \\
\hline BI & 0.726 & 0.627 & 0.853 & \\
\hline PEOU & 0.612 & 0.580 & 0.615 & 0.847 \\
\hline
\end{tabular}

TABLE 3. MODEL FIT INDICES

\begin{tabular}{|c|c|c|c|}
\hline Index & $\begin{array}{c}\text { Measurement } \\
\text { Model }\end{array}$ & Threshold & Suggested by Author (s) \\
\hline $\mathrm{x}^{\wedge} 2 / \mathrm{df}$ & 1.693 & $1<3.0$ & Hair, et. al. [48] \\
\hline GFI & 0.920 & $>0.9$ & Gefen et al., [5] \\
\hline AGFI & 0.901 & $>0.8$ & Gefen et al. [5] \\
\hline CFI & 0.978 & $>0.9$ & Anderson, et. al. [47] \\
\hline NFI & 0.948 & $<0.9$ & Anderson, et. al. [47] \\
\hline RMSEA & 0.042 & $<0.08$ & anett, 1980 \\
\hline
\end{tabular}

Mehran University Research Journal of Engineering \& Technology, Volume 36, No. 2, April, 2017 [p-ISSN: 0254-7821, e-ISSN: 2413-7219] 
statistical tools to empirically investigate proposed model and the factors affecting customer trust. Finding as shown in Fig. 2 indicate that the total variance of 53\% in BI is explained by predictors: PU (0.359), trust $(\mathrm{TR}=$ 0.412), and PEOU (0.161). Thus trust (TR) is found to be the most significant direct predictors of BI, followed by PU and PEOU. Similarly variance in PU is found to be $44 \%$, which is explained by PEOU (0.428) and TR (0.263) predictors, respectively. The results showed that these findings supported the proposed hypothesis. Results also indicate that trust is the most significant factor and an strong predictor of both BI and PU to use MCommerce. This implies that users' intention to use MCommerce is directly proportional to the increase of trust. Thus the finding of this research are consistent with previous research studies, conducted to understand the importance of trust in online banking information systems [22] and e-commerce [5]. Compared to previous studies the role of trust is complex in M-commerce as the user requires trusting on the unknown virtual vendor as well as users' need confidence in the confidentiality and security in online monetary transactions.
This research has some limitations. First, the data for this research was obtained from individuals in Pakistan using a cross-sectional (at a single point of time) quantitative approach. Second, the applicability of this research is constrained by small sample size and confined research area. Thus, additional samples and constructs should be taken to further examine the relationships before generalizing the results. Third, the proposed model was tested in Pakistan's context and findings may vary in other under developed economies. Additionally, the data for this research was collected under voluntary settings, which might not be the best.

The specific consequences identified through the belief elicitation process and empirically validated through this research provide important guidelines for M-commerce service providers, retailers, managers, technology consultants, software vendors, IS developers, investors and designers. Findings can guide them plan and optimize software platforms, prioritize service provisioning, formulate appropriate business strategies and improve their efficiency to enhance M-commerce adoption

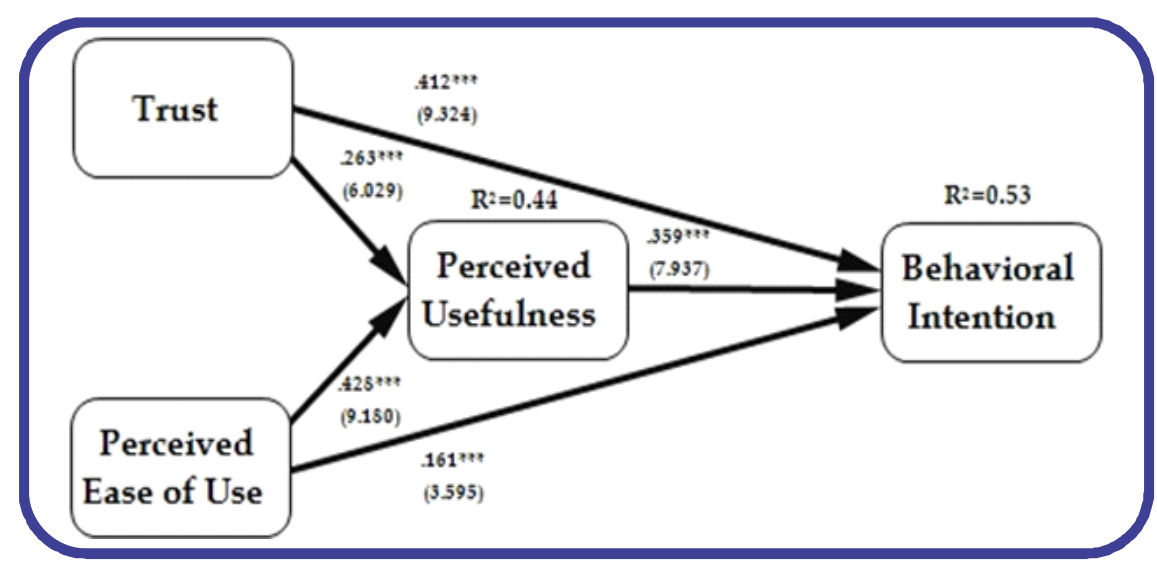

Notes: A number in parentheses indicates t-values. A number without parenthesis indicates â values. *** indicates that relations are highly significant at 0.001 level.

FIG. 2. MODEL SUPPORTED BY EMPIRICAL DATA 


\section{CONCLUSIONS}

With significant growth, maturity and unique advantages of wireless technology, mobile phone penetration ratio has touched the global population. Business entities have taken great advantages of IS and IT in expanding their consumer market, attracting and competing globally to maximize their sales by reshaping their sales strategies.

Being a new trend of electronic commerce, $\mathrm{M}$-commerce has received huge market attraction for both, the business organizations and consumers in a short span of time. MCommerce is a better choice for conducting daily commerce activities from anywhere and at any time. It is very important to analyze the main reasons of delay in large scale penetration of M-Commerce adoption in developing economies. Having realized the real benefits and huge market penetration in developed economies, M-Commerce seems to have huge market potential. It is observed that in developing countries academic research regarding $\mathrm{M}$-commerce acceptance is very trivial, as it is still new concept and is yet to be fully adopted by consumers in their routine life.

Therefore, in this paper we proposed a novel framework to find the role of trust in the acceptance of $\mathrm{M}$-commerce in Pakistan's context. Findings proved the hypothesized relationship among all constructs. Results indicate that the significant role of trust in the acceptance of $M$ commerce. At present Pakistani internet and mobile phone users have some doubts regarding their privacy risk, which in turn refrain them not to use mobile handheld device for carrying out commercial activities. We found that the role of trust is very crucial for the success and growth of Mcommerce.

\section{ACKNOWLEDGEMENT}

The authors thank the anonymous reviewers and the editors for their many helpful suggestions.
APPENDIX-A. MEASUREMENT ITEMS

- Behavior Intention

BI1: I intend to use the Mobile Commerce as often as needed.

BI2: I intend to continue using Mobile Commerce in the future.

BI3: $\quad$ Assuming I have access to Mobile Commerce, I intend to use it.

BI4: Given that I may have access to Mobile Commerce, I predict that I will use it.

BI5: I will strongly recommend others to use Mobile Commerce.

- $\quad$ Perceived Usefulness

PU1: Using Mobile Commerce helps me complete my tasks more swiftly.

PU2: Using Mobile Commerce increase my efficiency.

PU3: Using Mobile Commerce improves my performance.

PU4: Using Mobile Commerce enhances my effectiveness.

PU5: Using Mobile Commerce makes it easier for me to engage in online commercial activities.

- $\quad$ Perceived Ease of Use

PEOU1: Learning to use Mobile Commerce is easy for me.

PEOU2: Finding anything that I want via Mobile Commerce is simple.

PEOU3: My interaction with Mobile Commerce is clear and understandable.

PEOU4: I find Mobile Commerce to be flexible to interact.

- Trust

TR1: Mobile Commerce is trustworthy.

TR2: I am quite certain what to expect from Mobile Commerce.

TR3: I trust Mobile Commerce.

TR4: $\quad$ Mobile Commerce would do the job right even if not monitored. 


\section{REFERENCES}

[1] Anus, S., Qureshi, F.A., Malik, S., Abbasi, A., Chaudhry, A., and Mirza, S.N., "Trust and Initial Acceptance of Mobile Banking in Pakistan", Volume 2, No. 8, pp. 1-14, 2011.

[2] Tarasewich, P., Nickerson, R.C., and Warkentin, M.,"Issues in Mobile e-Commerce", Communications of the Association for Information Systems, Volume 8, No. 1, pp. 41-64, 2002.

[3] Wei, T.T., Marthandan, G., Chong, A.Y.-L., Ooi, K.-B., and Arumugam, S., "What Drives Malaysian MCommerce Adoption? An Empirical Analysis", Industrial Management \& Data Systems, Volume 109, No. 3, pp. 370-388, 2009.

[4] Cho, D.Y., Kwon, H.J., and Lee, H.Y., "Analysis of Trust in Internet and Mobile Commerce Adoption", Proceedings of Annual Hawaii International Conference on System Sciences, pp. 1-10, 2007.

[5] Gefen, D., Karahanna, E., and Straub, D., "Trust and TAM in Online Shopping: An Integrated Model”, MIS Quarterly, Volume 27, pp. 51-90, 2003.

PTA, "Annual Cellular Mobile Teledensity in Pakistan", Annual Cellular Mobile Teledensity, Available at: http://www.pta.gov.pk/index.php?option= com_content\&task=view\&id=269\&Itemid=658. [Accessed: 25-Aug-2015].

Nazir, S., Tayyab, A., Sajid, A., Rashid, H., and Javed, I.," How Online Shopping Is Affecting Consumers Buying Behavior in Pakistan?", International Journal of Computer Science Issues, Volume 9, No. 3, pp. 486-495, 2012.

[8] Shah, M.U., Fatimee, S., and Sajjad, M., "Mobile Commerce Adoption: An Empirical Analysis of the Factors Affecting", Journal of Basic and Applied, Volume 4, No. 4, pp. 80-88, 2014.

[9] Hosein, N. Z., "Internet Banking: An Empirical Study of Adoption Rates Among Midwest Community Banks", Journal of Business \& Economics Research, Volume 7, No. 11, 2011.

[10] Akhlaq, M.A., and Shah, A., "Internet Banking in Pakistan: Finding Complexities", Journal of Internet Banking and Commerce, Volume 16, No. 1, pp. 1-14, 2011.

[11] Mayer, R.C., Davis, J.H., and Schoorman, F.D., "An Integrative Model of Organizational Trust", Academy of Management Review, Volume 20, No. 3, pp. 709-734, 1995.

[12] Zahedi, F.M., and Song, J., "Dynamics of Trust Revision: Using Health Infomediaries", Journal of Management Information Systems, Volume 24, No. 4, pp. 225-48, 2008 .
[13] Nicolaou, A.I., and McKnight, D.H.," Perceived Information Quality in Data Exchanges: Effects on Risk, Trust, and Intention to Use", Information Systems Research, Volume 17, No. 4, pp. 332-351, 2006.

[14] Lowry, P.B., Vance, A., Moody, G., Beckman, B., and Read, A., "Explaining and Predicting the Impact of Branding Alliances and Web Site Quality on Initial Consumer Trust of e-Commerce Web Sites", Journal of Management Information Systems, Volume 24, No 4, pp. 199-224, 2008.

[15] Fuller, M.A., Serva, M.A., and Benamati, J., "Seeing is Believing: The Transitory Influence of Reputation Information on e-Commerce Trust and Decision Making", Decision Sciences, Volume 38, No. 4, pp. 675-699, 2007.

[16] Hoffman, D., Novak, T., and Peralta, M.A., "Building Consumer Trust Online", Communications of the ACM, Volume 42, pp. 80-85,1999.

[17] World Bank, "Annual Percentage Growth Rate of GDP", Retrieved from http://data.worldbank.org/country/ pakistan.Retrieved 2015.

[18] Shahnawaz, M., "Adoption of E-Commerce Amongst Pakistani Consumers A Case of Mobile Banking”, International Review of Management and Business Research, Volume 1, No. 3, pp. 385-396, 2014.

[19] Sattar, S., "Online Shopping Adaptation by Individuals in Pakistan", International Institute for Science, Technology and Education, Volume 4, No. 3, pp. 99-103, 2014.

[20] ITU-T, "ITU Releases 2014 ICT Figures”, 2014.

[21] Jurevièiûtë, E., "Key Factors Affecting Consumers "Intention to Use Mobile Commerce in Lithuania", Master Thesis [Manuscript], Vilnius, ISM University of Management and Economics, 2011.

[22] Chandio, F.H., "Studying Acceptance of Online Banking Information System: A Structural Equation Model", Doctoral Dissertation, Brunel University Brunel Business School, 2011.

[23] Joubert, J., and Belle, J.V., "The Role of Trust and Risk in Mobile Commerce Adoption within South Africa", International Journal of Business, Humanities and Technology, Volume 3, No. 2, 27-38, 2013.

[24] Kim, C., Mirusmonov, M., and Lee, I., "An Empirical Examination of Factors Influencing the Intention to Use Mobile Payment", Computers in Human Behavior, Volume 26, No. 3, pp. 310-322, 2010.

[25] Zhou, T., “An Empirical Examination of Initial Trust in Mobile Payment",Wireless Personal Communications, Volume 77, No. 2, pp. 1519-1531, 2014. 
[26] Davis, F.D., "Perceived Usefulness, Perceived Ease of Use, and User Acceptance of Information Technology", MIS Quarterly, Volume 13, No. 3, pp. 319-340, 1989.

[27] Faziharudean, T.M., and Li-ly, T., "Consumers' Behavioral Intentions to Use Mobile Data Services in Malaysia”, African Journal of Business Management, Volume 5, No. 5, pp. 1811-1821, 2011.

[28] Chong, A.Y.-L., Chan, F.T.S., and Ooi, K.-B., "Predicting Consumer Decisions to Adopt Mobile Commerce: Cross Country Empirical Examination between China and Malaysia", Decision Support Systems, Volume 53, No. 1, pp. 34-43, 2012

[29] Qingfei, M.I.N., Shaobo, J.I., and Gang, Q.U., "Mobile Commerce User Acceptance Study in China: A Revised UTAUT Model", Tsinghua Science and Technology, Volume, 13, No. 3, pp. 257-264, 2008.

[30] Gitau, L., and Nzuki, D., "Analysis of Determinants of M-Commerce Adoption by Online Consumers", International Journal of Business, Humanities and Technology, Volume 4, No. 3, pp. 88-94, 2014.

[31] Lin, H.-H., and Wang, Y.-S., "An Examination of the Determinants of Customer Loyalty in Mobile Commerce Contexts", Information \& Management, Volume 43, No. 3, pp. 271-282, 2006.

[32] Wu, J.-H., and Wang, S.-C.,"What Drives Mobile Commerce?", Information \& Management, Volume, 42, No. 5, pp. 719-729, 2005.

[33] Liao, C.-H., Tsou, C.-W., and Huang, M.-F., "Factors Influencing the Usage of $3 \mathrm{G}$ Mobile Services in Taiwan", Online Information Review, Volume 31, No. 6, 759$774,2007$.

[34] Wang, W., and Benbasat, I., "Trust in and Adoption of Online Recommendation Agents", Journal of the Association for Information Systems, Volume 6, No. 3, pp. 72-101, 2005.

[35] Khalifa, M., and Shen, K.N.," Explaining the Adoption of Transsactional B2C Mobile Commerce", Journal of Enterprise Information Management, Volume 21, No. 2, pp. 110-112, 2008.

[36] Gu, J.-C., Lee, S.-C., and Suh, Y.-H., "Determinants of Behavioral Intention to Mobile Banking", Expert Systems with Applications, Volume 36, No. 9, pp. 11605$11616,2009$.

[37] Liao, C., To, P.-L., Liu, C.-C., Kuo, P.-Y., and Chuang, S.-H., "Factors Influencing the Intended Use of Web Portals", Online Information Review, Volume 35, No. 2, pp. 237-254, 2011.

[38] Guriting, P., and Ndubisi, N.O.," Borneo Online Banking: Evaluating Customer Perceptions and Behavioural Intention", Management Research News, Volume 29, Nos. 1/2, pp. 6-15, 2006.
Sun, Q., Cao, H., and You, J.,"Factors Influencing the Adoption of Mobile Service in China", An Integration of TAM, Journal of Computers, Volume 5, No. 5, pp 799-806, 2010.

[40] Dai, H., and Palvia, P.C., "Mobile Commerce Adoption in China and the United States: A Cross-Cultural Study", The Database for Advances in Information Systems, Volume 40, No. 4, pp. 43-61, 2010.

[41] Mallat, N., Rossi, M., Tuunainen, V.K., and Öörni, A., "The Impact of Use Situation and Mobility on the Acceptance of Mobile Ticketing Services", 39th Hawaii International Conference on System Sciences, pp. 1-10, 2006.

[42] Moon, J.W., and Kim, Y.G., "Extending the TAM for a World Wide Web Context", Information and Management, Volume 38, No. 4, pp. 217-230, 2001.

[43] Doney, P.M., and Cannon, J.P., "An Examination of the Nature of Trust in Buyer-Seller Relationships", Journal of Marketing, Volume 61, No. 1, pp. 35-51, 1997.

[44] Venkatesh, V., and Davis, F.D., "A Theoretical Extension of the Technology Acceptance Model: Four Longitudinal Field Studies", Management Science, Volume 46, No. 2, pp. 186-204, 2000.

[45] Comrey, L.A., and Lee, H.B., "A First Course in Factor Analysis", $2^{\text {nd }}$ Edition, Lawrence Erlbaum Associates Inc., New Jersey, 1992.

[46] Alavifar, A., Karimimalayer M., and Anuar, M.K., "Structural Equation Modeling VS Multiple Regression", IRACST - Engineering Science and Technology: An International Journal, Volume 2, 2012.

[47] Anderson, J.C., and Gerbing, D.W., "Structural Equation Modeling in Practice: A Review and Recommended TwoStep Approach", Psychological Bulletin, Volume 103, pp. 411-423, 1988.

[48] Hair, J.F., Anderson, R.E., Tatham, R.L., and Black, W.C., "Multivariate Data Analysis", 5th Edition, Prentice Hall, Upper Saddle River, NJ, 1998.

[49] Byrne, B.M., "Structural Equation Modeling with AMOS: Basic Concepts, Applications, and Programming", Routledge, 2013.

[50] Fornell, C., and Larcker, D.F., "Evaluating Structural Equation Models with Unobservable Variables and Measurement Error", Journal of Marketing Research, Volume 18, No. 1, pp. 39-50, 1981. 